\title{
Human capital depreciation during hometime
}

\author{
Citation for published version (APA):
}

Görlich, D., \& de Grip, A. (2009). Human capital depreciation during hometime. Oxford Economic PapersNew Series, 61(1), i98-i121. https://doi.org/10.1093/oep/gpn044

Document status and date:

Published: 01/01/2009

DOI:

10.1093/oep/gpn044

Document Version:

Publisher's PDF, also known as Version of record

Document license:
Taverne

\section{Please check the document version of this publication:}

- A submitted manuscript is the version of the article upon submission and before peer-review. There can be important differences between the submitted version and the official published version of record.

People interested in the research are advised to contact the author for the final version of the publication, or visit the DOI to the publisher's website.

- The final author version and the galley proof are versions of the publication after peer review.

- The final published version features the final layout of the paper including the volume, issue and page numbers.

Link to publication

\footnotetext{
General rights rights.

- You may freely distribute the URL identifying the publication in the public portal. please follow below link for the End User Agreement:

www.umlib.nl/taverne-license

Take down policy

If you believe that this document breaches copyright please contact us at:

repository@maastrichtuniversity.nl

providing details and we will investigate your claim.
}

Copyright and moral rights for the publications made accessible in the public portal are retained by the authors and/or other copyright owners and it is a condition of accessing publications that users recognise and abide by the legal requirements associated with these

- Users may download and print one copy of any publication from the public portal for the purpose of private study or research.

- You may not further distribute the material or use it for any profit-making activity or commercial gain

If the publication is distributed under the terms of Article $25 \mathrm{fa}$ of the Dutch Copyright Act, indicated by the "Taverne" license above, 


\title{
Human capital depreciation during hometime
}

\section{By Dennis Görlich* and Andries de Grip†}

*The Kiel Institute for the World Economy, 24100 Kiel, Germany

$\uparrow$ Research Centre for Education and the Labor Market (ROA), Faculty of Economics and Business Administration, Maastricht University, Netherlands, and IZA, Bonn; e-mail: a.degrip@roa.unimaas.nl

\begin{abstract}
We estimate human capital depreciation rates during career interruptions due to family reasons (parental leave and household time) in male- and female-dominated occupations. If human capital depreciation due to family related career breaks is lower in female than in male occupations, this can explain occupational sex segregation because women will take the costs of future breaks into account when optimizing their lifetime earnings. We find that short-run depreciation rates in high-skilled occupations are significantly lower in female than in male occupations. In low-skilled occupations, there is no evidence of this difference. Our findings support the selfselection hypothesis with respect to occupational sex segregation in the more skilled jobs, i.e. high-skilled women might deliberately choose female occupations because of the lower short-term wage penalties for family-related career interruptions.
\end{abstract}

JEL classifications: J24, J16, J13.

\section{Introduction}

In the past decades, many studies analysed the occupational segregation between male and female workers (cf. Beller, 1982; Karmel and Maclachlan, 1988; Boisso, 1994). Although occupational segregation by gender could reflect efficiency reasons and individual preferences, it is also responsible for a large part of the gender wage gap because women are overrepresented in lower paying occupations (cf. Fain, 1998; Reed and Dahlquist, 1994; Jurajda and Harmgart, 2003). Moreover, there are fewer career opportunities in female occupations than in male occupations (Jacobsen, 1998). For these latter reasons, it is often argued that occupational segregation is a result of discrimination of female workers.

However, occupational segregation by gender may also be caused by selfselection. One indicator for this might be that job satisfaction of women is higher in workplaces dominated by female workers (Bender et al., 2005), but the empirical evidence is mixed. Some studies found that women self-select into female occupations because these occupations offer more pleasant working conditions, flexibility (Filer, 1985; Bender et al., 2005), and more family-friendly human 
resource policies (Datta Gupta and Smith, 2000; Nielsen et al., 2004). ${ }^{1}$ Other studies could not verify self-selection motivated by such workplace amenities (Reed and Dahlquist, 1994; Trappe and Rosenfeld, 2004). ${ }^{2}$ The relevance of self-selection is also supported by Borghans and Groot (1999) who found that educational segregation is a major cause of occupational segregation by gender. It is interesting to note in that respect that public policies attempt to tackle occupational sex segregation by affecting educational pre-sorting. A prominent example in many countries is the effort taken to encourage interest in technical studies among girls. Such policies implicitly assume that women choose female occupations due to a lack of information about male occupations.

Yet, there may be a major financial reason for self-selection: if women plan to eventually interrupt their career for family reasons (e.g. pregnancy, child rearing, household tasks), they may optimize their life-time earnings if they chose to work in an occupation in which the wage 'penalty' for an interruption is low. In other words, the wage decrease resulting from human capital depreciation during a family-related career interruption may be lower in female occupation than in male occupations (cf. Polachek, 1981). McDowell (1982) found support for this self-selection argument, by analysing the durability of knowledge in different disciplines. He found that women who pursue an academic career are more often employed in disciplines like humanities where knowledge depreciates more slowly during a career interruption.

In this paper, we analyse whether human capital depreciation during familyrelated career interruptions is lower in female occupations than in male occupations. If this is the case, it indicates that occupation-specific depreciation rates during family-related career breaks may affect occupational sex segregation by self-selection. The depreciation rates of six different occupational groups will be estimated in a fixed-effects model using the 12 panel waves 1994-2005 from the German SocioEconomic Panel (GSOEP). We distinguish six occupational groups: male, integrated, and female occupations with high and low skill requirements, respectively.

Our study contributes to the literature in several ways. First, unlike other studies (e.g. Mincer and Polachek, 1978; Polachek, 1981; England, 1982; Kunze, 2002), we focus on human capital deprecation during family-related career interruptions. We do this because only interruptions due to family reasons can influence a person's occupational choice ex ante, as these interruptions are the only type of interruptions that can be anticipated to a large extent. Moreover, family-related career interruptions are currently the main difference in male and female patterns of labour market participation (Datta Gupta and Smith, 2002).

\footnotetext{
${ }^{1}$ These arguments refer to the traditional theory of compensating wages, since it seems that women trade in a part of their wage for more amenities, which are not enjoyed in male occupations. Consequently, female occupations feature a lower pay level according to this theory.

${ }^{2}$ Also Lewis and Shorten (1991), Fain (1998), and Hansen and Wahlberg (2000) found support for the self-selection theory, using Australian, US, and Swedish data, respectively. However, thesestudies do not distinguish between financial and other determinants.
} 
Second, we analyse whether human capital depreciation rates differ between highand low-skilled occupations, whereas other studies either focus on only one skill level (Kunze, 2002), or on human capital depreciation rates related to the worker's level of education, instead of the skill level of the occupation (Mincer and Polachek, 1974). Distinguishing between low-skilled and high-skilled occupations is more sensible in our context as the individual level of education is not necessarily connected to occupational choice (see e.g. Groot and Maassen van den Brink, 2000).

Third, in contrast to other studies (England, 1982; Polachek, 1981), we distinguish between short- and long-run human capital depreciation effects of career interruptions, as both effects might influence the decision to interrupt the career differently.

Our main finding is that, in the short run, human capital depreciation during family-related career interruptions is significantly lower in female high-skilled occupations than in male high-skilled occupations. However, for low-skilled occupations, we do not find a significant difference between the depreciation rates in male and female occupations. For the more skilled jobs, our results support Polachek's (1981) hypothesis that occupational sex segregation is the result of women's self-selection into female occupations on the basis of anticipated human capital depreciation rates. Moreover, we find that short-run depreciation rates after a career break due to family reasons have a similar magnitude as human capital depreciation during career breaks due to unemployment.

\section{Prior research}

The skills of workers with career interruptions can depreciate because they may not be using or updating them during the interruption. More precisely, they may be subject to technical as well as economic obsolescence of their human capital: they may face atrophy (i.e. loss of skill due to limited or non-use), skills obsolescence due to technological and organizational developments (i.e. loss in the value of a worker's skill due to non-updating), and firm-specific human capital obsolescence (i.e. loss in the value of the worker's skill due to firm change) (De Grip and Van Loo, 2002). In an attempt to directly measure the impact of career interruptions on skills, Edin and Gustavsson (2008) showed that time out of work indeed decreases literacy scores.

A common way to measure the actual rate of this human capital depreciation is to extend Mincer's (1974) earnings function, so that it can account for heterogeneous employment histories of workers, and therefore incorporates information on possible career interruptions (see e.g. Mincer and Polachek, 1974; Polachek, 1981; Light and Ureta, 1995; Beblo and Wolf, 2003).

In its simplest form, the earnings equation allowing for human capital depreciation looks as follows (Mincer and Polachek, 1974):

$$
\ln E_{t}=\ln E_{0}+\sum_{i=0}^{t-1}\left(r k_{i}-\delta_{i}\right),
$$


where $E_{t}$ is a person's earnings potential at time $t, E_{0}$ is initial earnings potential, $r$ is the rate of return to human capital investment, $k_{i}$ is the gross human capital investment ratio in period $i$ (i.e. human capital investment divided by earnings in period $i$ ), and $\delta_{i}$ measures the depreciation rate. Note that $\delta$ might vary over $i$, i.e. it might be different at different points in time.

In order to make eq. (1) estimable, Mincer and Polachek (1974) include periods of career interruptions:

$$
\ln E_{t}=\ln E_{0}+\left(r s-\delta_{s}\right)+\left(r k_{1}-\delta_{1}\right) e_{1}+\left(r k_{h}-\delta_{h}\right) h+\left(r k_{2}-\delta_{2}\right) e_{2},
$$

where $r$ is return to human capital investments and $\delta_{s}$ is the depreciation rate of the schooling, $e_{1}$ is the duration of the working spell before the interruption, $h$ is the duration of the career interruption, and $e_{2}$ is the working spell after the interruption. If it is assumed that human capital investment $k_{h}$ is zero during home time $h$, the regression coefficient of $h$ (i.e. $r k_{h}-\delta_{h}$ ) is an estimator of the human capital depreciation rate. As expected, they find a negative coefficient for home time. Similarly, Light and Ureta (1995), whose work history model is a refined version of the standard models, show that early-career wage growth estimates are downward-biased in standard models because negative wage effects of career interruptions are included in the estimates.

According to Mincer and Ofek (1982), human capital depreciation rates can be different depending on the point in time when these rates are measured, i.e. there are short-run and long-run depreciation rates. In their study, they distinguish four phases in a worker's career: (i) the working spell before the interruption, (ii) the non-working spell, (iii) the so-called restoration period, and (iv) the post-restoration period. Directly after a career interruption, the wage of the worker is considerably lower than before. Moreover, post-interruption wages are lower the longer is the interruption. However, wages increase rapidly during the restoration period, because during this phase previously eroded human capital is restored and such a process is quicker and less costly than building up completely new human capital. Eventually, wage growth slows down and continues to grow at a rate similar to that of a worker who does not interrupt his career. Their empirical results support this theory.

Obviously, career interruptions are not only due to family reasons, but also to unemployment, sick leave, or other events. Different types of career interruptions may lead to different magnitudes of the wage effect, because there might be a signalling or stigma effect connected to certain types of interruptions. For example, a period of parental leave might convey a more positive signal to a potential employer than a period of unemployment. Moreover, the effect of the former might differ between men and women. Albrecht et al. (1999) found a negative stigma effect after parental leave for Swedish men, while parental leave has no effect on women's wages. ${ }^{3}$ In a similar study for Germany, Beblo and

\footnotetext{
${ }^{3}$ They included parental leave, household time, other time out, unemployment, and military leave. Interruptions other than parental leave affected both men's and women's wages negatively.
} 
Wolf (2002b; 2003) extended the work history model with different types of career breaks. They found that parental leave has a stronger negative effect on women's wages than other types of interruptions. However, their findings on the effects of parental leave for women stand in stark contrast to the results of Albrecht et al. (1999) in Sweden, although the models used in the two studies are similar. This indicates that the wage effects of career interruptions may be highly sensitive to different national labour market institutions or cultural values.

Polachek (1981) suggested a direct link between human capital depreciation rates and occupational choice. He argued that women, who expect to interrupt their careers in order to take care of the family, will choose occupations where the penalty for their absence due to human capital depreciation is lowest, as this will maximize their lifetime income. If female occupations feature the lowest human capital depreciation rates, and women sort themselves into these jobs, human capital depreciation rates could be part of the explanation for occupational sex segregation. Polachek indeed found that human capital depreciation rates are highest in professional and managerial occupations, which are predominantly male occupational groups, while human capital of workers doing e.g. household work (a female dominated occupation) hardly depreciates at all. ${ }^{4}$

A major problem with Polachek's conclusions is that he does not directly test the influence of depreciation rates on occupational sex segregation, because his choice of occupational groups does not reflect the extent of segregation in these groups. England (1982) corrected for this by constructing occupational groups according to the degree of 'femaleness'. However, she did not find any evidence for occupational self-selection motivated by lower depreciation rates. ${ }^{5}$ Moreover, England showed that not only women with career interruptions work in female occupations, but also those in continuous employment. Accordingly, she argued that human capital theory fails to account for occupational segregation, so that she proposed discrimination as the culprit. Kunze (2002) conducted a similar study for 'young skilled workers' in Germany and did not find support for Polachek's theory, either. In contrast to England, she analysed depreciation rates for different types of interruptions and found that women on parental leave experience lower depreciation rates in male and integrated occupations. Consequently, she concluded that occupational sex segregation does not result from self-selection motivated by lower depreciation rates. However, Kunze only focused on the registered maternity and parental leave of young women who participated in apprenticeship training, which results in a rather selective sample.

\footnotetext{
${ }^{4}$ Although Polachek refers to the atrophy rate, his estimate of human capital depreciation might also measure skills obsolescence due to technological change.

${ }^{5}$ Remarkably, England found significantly higher human capital depreciation rates in occupations with a high fraction of females.
} 


\section{Hypotheses}

This study examines the role that family-related career interruptions can play in occupational sex segregation. For this purpose, we test whether human capital depreciation rates during family-related career interruptions are lower in female occupations than in male occupations, which might be a motivation for women who expect to interrupt their career for family reasons to deliberately select female occupations. Unlike the above-mentioned studies by Polachek (1981) and England (1982), we explicitly focus on the wage effects of family-related career interruptions. We focus on these because, unlike other types of career interruptions, familyrelated interruptions are voluntary and can be anticipated. ${ }^{6}$ Moreover, these interruptions often take place rather early in a worker's career. This early stage might imply that women are more able to take it into account at the time of their occupational choice (cf. Beblo and Wolf, 2002a).

Furthermore, German legislation offers a system with long potential formal parental leave. ${ }^{7}$ This gives family-related career interruptions a special importance on the German labour market, and might therefore have a significant influence on occupational choice.

Moreover, the wage effects of formal parental leave are probably different from the effects of other types of career interruptions, because special costs and benefits are connected to it. On the benefit side, parental leave policies encourage continued labour force attachment of women and retain specific human capital for the firm (Ondrich et al., 2002; Hashimoto et al., 2004). On the cost side, such policies decrease labour market flexibility, and raise labour costs, because a firm might need to hire and train temporary workers to replace women who are on parental leave. These costs might be passed on to the returning mother in form of lower wages (Ondrich et al., 2002).

We follow Beller (1982) in defining occupational groups according to the percentage of women employed in it. We distinguish three categories of occupations: male occupations, integrated occupations, and female occupations. Moreover, we distinguish between high- and low-skilled occupations. We do this for two reasons. First, skill level requirements of an occupation can influence the size of the depreciation rate (Mincer and Polachek, 1978; Neuman and Weiss, 1995). Second, sex segregation of high-skilled occupations could have different determinants than segregation of low-skilled occupations. This leaves us with six occupational

\footnotetext{
${ }^{6}$ A career interruption due to unemployment can also be voluntary, but we assume here that unemployment is often involuntary. Another voluntary type of career interruptions are sabbaticals, but sabbaticals hardly occur in our sample.

${ }^{7}$ While maternity leave in the US only spans 12 weeks (Hashimoto et al., 2004), it varies from 12 weeks to three years in European countries (Ruhm, 1998). In Germany, parents (thus both mothers and fathers) are entitled to parental leave until the third birthday of their child with full guarantee to return to their old workplace (Merz, 2004).
} 
groups: male, integrated, and female occupations with high skill requirements, and male, integrated, and female occupations with low skill requirements.

If women self-select into female occupations on the basis of lower depreciation rates, we expect significantly lower depreciation rates in female occupations, as compared to male occupations. A validation of the following two hypotheses would thus be support for the theory of self-selection on basis of deprecation rates (Polachek, 1981).

Hypothesis 1 The depreciation rate of human capital in high-skilled male occupations is greater than the depreciation rate in high-skilled female occupations:

$$
\delta_{H, \text { male }}>\delta_{H, f e m}
$$

Hypothesis 2 The depreciation rate of human capital in low-skilled male occupations is greater than the depreciation rate in low-skilled female occupations:

$$
\delta_{L, \text { male }}>\delta_{L, f e m}
$$

We will test these hypotheses for both short- and long-run depreciation rates, because it is not clear a priori, which of the two is taken into account for occupational choice.

\section{Data}

For our analysis, we use data from the German Socio-Economic Panel (GSOEP). The GSOEP offers detailed data on a person's employment history distinguishing between unemployment spells, and spells during which one was off the labour market due to family reasons. We will use the 12 panel waves from 1994 until 2005. The sample will be restricted to those living in West Germany, as the East German labour market still has characteristics very different from the West German market. This holds more in general but also when it comes to career interruptions due to family reasons (see e.g. Rosenfeld et al., 2004).

Our sample contains all men and women from the age of 20 to 55 who were employed in one or more of the years 1994-2005. We include both full-time and part-time workers. All self-employed persons are excluded, as well as those who have just started their first job. The sample consists of 30,643 observations, made up of 4,342 individuals from which 711 are present in all 12 waves. All other persons are present in at least one other wave. Descriptive statistics of the variables are shown in Table 1. Note that this sample size only holds for the descriptive statistics and stylized facts. As we focus our analyses on female workers, the regressions are based on a sample of 13,536 observations, made up of 2,095 individuals.

\section{Description and construction of variables}

Hourly wages are reported in euros and are deflated by the CPI with the year 2000 as reference year (Federal Statistics Office, 2007). The monthly wage, which is reported by the individuals in the GSOEP questionnaire, includes overtime pay. 
Table 1 Descriptive statistics

\begin{tabular}{|c|c|c|c|c|}
\hline \multirow[t]{2}{*}{ Variable } & \multicolumn{2}{|c|}{ A. Overall } & \multicolumn{2}{|c|}{ B. Women } \\
\hline & Mean & Std. dev. & Mean & Std. dev. \\
\hline Gross hourly wage (in 2000 prices) & 13.48 & 7.847 & 11.68 & 8.256 \\
\hline Gender (male) & 0.55 & 0.497 & & \\
\hline Age & 38.54 & 9.237 & 38.60 & 9.374 \\
\hline $\mathrm{Age}^{2}$ & 1571.02 & 714.213 & 1577.56 & 720.326 \\
\hline $\mathrm{Age}^{3}$ & 67101.13 & 43592.570 & 67588.48 & 43736.970 \\
\hline Firm size: $<20$ & 0.23 & 0.419 & 0.30 & 0.458 \\
\hline Firm size: $20-99$ & 0.10 & 0.297 & 0.10 & 0.302 \\
\hline Firm size: $100-199$ & 0.18 & 0.384 & 0.18 & 0.384 \\
\hline Firm size: $200-1999$ & 0.24 & 0.429 & 0.23 & 0.418 \\
\hline Firm size: $>2000$ & 0.25 & 0.433 & 0.19 & 0.394 \\
\hline Working in public sector & 0.25 & 0.431 & 0.30 & 0.460 \\
\hline Firm change & 0.09 & 0.285 & 0.09 & 0.288 \\
\hline Working in high-skilled occupation & 0.38 & 0.485 & 0.40 & 0.490 \\
\hline Working in male occupation & 0.45 & 0.498 & 0.15 & 0.360 \\
\hline Working in integrated occupation & 0.24 & 0.427 & 0.28 & 0.449 \\
\hline Working in female occupation & 0.31 & 0.461 & 0.57 & 0.496 \\
\hline \multicolumn{5}{|l|}{ Career interruptions } \\
\hline Unemployment (short-run) & 0.27 & 0.767 & 0.28 & 0.756 \\
\hline Unemployment (long-run) & 0.70 & 1.554 & 0.72 & 1.429 \\
\hline Other (short-run) & 0.08 & 0.324 & 0.08 & 0.323 \\
\hline Other (long-run) & 0.25 & 0.931 & 0.30 & 1.107 \\
\hline Family (short-run) & 0.68 & 1.430 & 1.39 & 1.834 \\
\hline Family (long-run) & 2.26 & 4.737 & 4.82 & 6.082 \\
\hline \multicolumn{5}{|l|}{ Family-related interruption in occupation } \\
\hline High-skilled (short-run) & 0.24 & 0.911 & 0.50 & 1.283 \\
\hline Low-skilled (short-run) & 0.43 & 1.193 & 0.89 & 1.617 \\
\hline High-skilled (long-run) & 0.73 & 2.784 & 1.55 & 3.944 \\
\hline Low-skilled (long-run) & 1.53 & 4.115 & 3.28 & 5.618 \\
\hline High-skilled male (short-run) & 0.04 & 0.357 & 0.07 & 0.495 \\
\hline High-skilled integrated (short-run) & 0.07 & 0.517 & 0.15 & 0.745 \\
\hline High-skilled female (short-run) & 0.13 & 0.686 & 0.28 & 0.995 \\
\hline Low-skilled male (short-run) & 0.07 & 0.451 & 0.10 & 0.583 \\
\hline Low-skilled integrated (short-run) & 0.10 & 0.602 & 0.20 & 0.856 \\
\hline Low-skilled female (short-run) & 0.27 & 0.979 & 0.59 & 1.391 \\
\hline High-skilled male (long-run) & 0.12 & 1.009 & 0.20 & 1.377 \\
\hline High-skilled integrated (long-run) & 0.22 & 1.601 & 0.48 & 2.338 \\
\hline High-skilled female (long-run) & 0.39 & 2.117 & 0.86 & 3.093 \\
\hline Low-skilled male (long-run) & 0.24 & 1.588 & 0.44 & 2.284 \\
\hline Low-skilled integrated (long-run) & 0.34 & 2.032 & 0.73 & 2.940 \\
\hline Low-skilled female (long-run) & 0.95 & 3.397 & 2.11 & 4.823 \\
\hline Observations & 30,643 & & 13,736 & \\
\hline
\end{tabular}

Note: Interruption variables distinguish between short- and long-run. Short-run spells show the number of years in which the individual had an interruption spell within the most recent five years. Long-run spells show the number of years with an interruption spell more than five years ago. Real wages are obtained by deflating using the CPI in 2000 . 
Table 2 Skill levels of occupational groups (one-digit ISCO code)

\begin{tabular}{|c|c|c|c|c|}
\hline Level & Skill level & ISCO & Description & Education \\
\hline Low-skilled & $\begin{array}{l}1 \mathrm{st} \\
2 \mathrm{nd}\end{array}$ & $\begin{array}{l}9 \\
4-8\end{array}$ & $\begin{array}{l}\text { Elementary occupations } \\
\text { Clerks; } \\
\text { Service workers and shop/market sales workers } \\
\text { Skilled agricultural and fishery workers } \\
\text { Craft and related trades workers } \\
\text { Plant and machine operators and assemblers } \\
\text { Armed forces }\end{array}$ & $\begin{array}{l}\text { Primary } \\
\text { Vocational }\end{array}$ \\
\hline High-skilled & $\begin{array}{l}\text { 3rd } \\
\text { 4th } \\
\text { Varying }\end{array}$ & $\begin{array}{l}3 \\
2 \\
1\end{array}$ & $\begin{array}{l}\text { Technicians and associate professionals } \\
\text { Professionals } \\
\text { Legislators }\end{array}$ & $\begin{array}{l}\text { Technical college } \\
\text { Unversity }\end{array}$ \\
\hline
\end{tabular}

Source: ILO (2004), own classification.

We therefore calculate the hourly wage rate by dividing reported monthly wages by the reported actual number of working hours, in which overtime hours are included.

Several standard 'Mincer variables' are included. Age is included to capture wage growth due to experience. ${ }^{8}$ In order to capture the generally higher wage for workers in high-skilled occupations, a dummy for being employed in an occupation with high skill requirements is included. ${ }^{9}$ Wages also differ between the private and public sector of the economy. Accordingly, a dummy for public sector employment is introduced. Moreover, firm size dummies are introduced, with firms employing one to 19 employees serving as reference level. Finally, a dummy indicates a worker's change of firms in the previous year.

\subsection{Construction of occupational groups}

We construct six occupational groups according to the degree of segregation and the occupation's skill level. In the skill dimension, the occupations are categorized on basis of the reported ISCO- 88 codes. Table 2 shows the skill levels of the occupational groups. As in several other studies (see e.g. Fitzenberger et al., 2004), we classify occupations that require technical college or university education as highskilled occupations (3rd and 4th skill level), while jobs requiring a vocational degree and jobs that do not require any degree are classified as medium- and low-skilled occupations, respectively (1st and 2nd skill level). However, due to the very small number of elementary occupations, we pool medium- and low-skilled occupations

\footnotetext{
${ }^{8}$ We also include $\mathrm{Age}^{2}$ and $\mathrm{Age}^{3}$. The latter could correct for the bias that older workers have had more interruptions in the past than younger workers.

${ }^{9}$ Note that the dummy does not say anything about the worker's education, but only about the skill level of the occupation he or she is working in.
} 
Table 3 Largest occupations in each occupational group

\begin{tabular}{lc}
\hline & $\begin{array}{l}\text { Share of women } \\
\text { (in \%) }\end{array}$ \\
& \\
\hline Male occupations & \\
High-skilled & 7.01 \\
Architects, engineers and related professionals & 23.25 \\
Physical and engineering science technicians & 23.88 \\
Other specialist managers & \\
Low-skilled & 7.68 \\
Machinery mechanics and fitters & 5.35 \\
Building finishers and related trades workers & 22.34 \\
Motor vehicle drivers & \\
Integrated occupations & \\
High-skilled & 48.66 \\
Finance and sales associate professionals & 55.99 \\
Secondary education teaching professionals & 42.39 \\
Public service administrative professionals & \\
Low-skilled & 59.38 \\
$\quad$ Numerical clerks & 45.27 \\
Material-recording and transport clerks & 60.29 \\
Housekeeping and restaurant services workers & \\
Female occupations & \\
High-skilled & 77.34 \\
Administrative associate professionals & 84.62 \\
Nursing and midwifery associate professionals & 91.35 \\
Pre-primary education teaching associate professionals & \\
Low-skilled & 85.13 \\
Shop, stall and market salespersons and demonstrators \\
Personal care and related workers & 88.45 \\
Other office clerks & 87.96 \\
\hline
\end{tabular}

Source: GSOEP, using the pooled cross sections 2004-2005, own calculations.

Note: In each group the occupations are listed in descending order of total employment in the occupation.

and denote them together as low-skilled occupations. ${ }^{10}$ With respect to the occupational segregation dimension, there seems to be a consensus in the literature to classify occupations that are comprised of more than two-thirds of female workers as female occupations, occupations with less than one-third as male occupations, and the rest as integrated occupations (cf. Hansen and Wahlberg, 2000).

Note that, in order to classify occupations by their predominant gender, they first have to be distinguished at a particular level of aggregation. This is done at the level of the three-digit ISCO codes (see Table A1 in the Appendix). Table 3 lists the three largest three-digit occupations in the six occupational groups we distinguish.

\footnotetext{
${ }^{10}$ The skill levels of legislators and members of the armed forces vary, but are here classified as high- and low-skilled, respectively (cf. Fitzenberger et al., 2004).
} 


\subsection{Demarcation of short- and long-run depreciation rates}

As found by Mincer and Ofek (1982), wages increase quite rapidly in the first years after a career interruption (restoration phase), and settle down to the average level after a while. Therefore, it is sensible to define the short-run as the period starting right after the interruption, and ending when the restoration phase is over. However, the existing literature does not offer a consistent estimate of the duration of the restoration phase. Estimates range from recovery after one year (Light and Ureta, 1995), to recovery after five years (Mincer and Ofek, 1982; Nielsen et al., 2004). The two German studies (Beblo and Wolf, 2002b; Kunze, 2002) did not find any evidence of recovery of women's wages after formal parental leave. In these studies, the interruptions continue to have a negative wage effect even after several years. Note however, that the latter studies do not truly show wage growth after an interruption, but rather the effect of an interruption that might well continue to be present in the long-run despite higher wage growth in the short run. We therefore decided to stick with a restoration phase of five years as it has been originally estimated by Mincer and Ofek.

\subsection{Construction of career interruption variables}

We distinguish between three different kinds of career interruptions: (i) career interruptions due to family reasons, (ii) career interruptions due to unemployment, and (iii) career interruptions due to other reasons. We define 'family reasons' as an aggregate of formal parental leave periods and household time. ${ }^{11}$ Career interruptions due to other reasons are not further specified, but might include sabbaticals, periods of sick leave, or care for elderly family members. Unemployment and other interruption periods are included mainly as controls, but also to compare their wage effects to those of family-related interruptions.

For all three interruption types, a short-run and long-run variable is constructed (e.g. $f a m_{s r}$ and $f a m_{l r}$ ), where 'short-run' refers to spells within the last five years and 'long-run' refers to spells before that time. Both the short-run and long-run variables contain the number of years in which a person had an interruption spell. Note that each career interruption appears only once, i.e. either in the shortor long-run variable. We obtain separate estimates for the six occupational groups by interacting $\mathrm{fam}_{s r}$ and $\mathrm{fam}_{l r}$ with the dummies for high-skilled and low-skilled occupations, and with the dummies for male, integrated, and female occupations.

\footnotetext{
${ }^{11}$ Household time means that a person has reported to be a housewife or househusband. We included household time in the career interruptions for family reasons because this is the traditional label for it (cf. Mincer and Polachek, 1974). This is reflected in the fact that an explicit reference to 'parental leave' is only included in the GSOEP since 1991.
} 
Table 4 Incidence of recent family-related career interruptions by occupational group

\begin{tabular}{|c|c|c|c|c|c|c|}
\hline \multirow[b]{2}{*}{ Occupation } & \multicolumn{2}{|c|}{ A. Overall } & \multicolumn{2}{|c|}{ B. Women } & \multicolumn{2}{|c|}{ C. Men } \\
\hline & $\begin{array}{l}\text { Interruption } \\
(\%)\end{array}$ & $\begin{array}{l}\text { Total } \\
\text { (no.) }\end{array}$ & $\begin{array}{l}\text { Interruption } \\
(\%)\end{array}$ & $\begin{array}{l}\text { Total } \\
\text { (no.) }\end{array}$ & $\begin{array}{l}\text { Interruption } \\
(\%)\end{array}$ & $\begin{array}{l}\text { Total } \\
\text { (no.) }\end{array}$ \\
\hline High-skilled male & 10.54 & 529 & 33.43 & 346 & 4.59 & 183 \\
\hline High-skilled integrated & 23.37 & 825 & 38.92 & 741 & 5.17 & 84 \\
\hline High-skilled female & 36.71 & 1,323 & 44.37 & 1,260 & 8.25 & 63 \\
\hline Low-skilled male & 9.78 & 909 & 40.56 & 464 & 5.46 & 445 \\
\hline Low-skilled integrated & 25.25 & 1,065 & 42.82 & 922 & 6.93 & 143 \\
\hline Low-skilled female & 44.44 & 2,695 & 50.72 & 2,632 & 7.20 & 63 \\
\hline Total & 23.15 & 7,346 & 44.62 & 6,365 & 5.62 & 981 \\
\hline Total no. of observations & & 31,727 & & 14,265 & & 17,462 \\
\hline
\end{tabular}

Source: GSOEP, pooled cross sections 1994-2005; own calculations.

\section{Some stylized facts}

The GSOEP data show that in West Germany $86.3 \%$ of all family-related employment breaks within the most recent five years were taken by women. ${ }^{12}$ Indeed, only $5.6 \%$ of all working men took an employment break for family reasons within the last five years, compared to $44.6 \%$ of all working women.

Next, it is interesting to check whether workers who interrupt their careers are working in male, female, or integrated occupations because we suspect female occupations to be more suitable for career interruptions. Table 4 shows that the highest fraction of workers with a recent career interruption is indeed found in female occupations. Interestingly, this holds for both women and men. Whereas $44.4 \%$ of the women employed in the high-skilled female occupations had a familyrelated career interruption in the last five years, only $33.4 \%$ of the women employed in the high-skilled male occupations had a career break. For the male workers who are employed in these occupations the rates are $8.3 \%$ and $4.6 \%$, respectively. The latter indicates that it might indeed be less costly to have a family-related career break in female occupations.

\section{Model}

We estimate the following fixed-effects model with robust standard errors:

$$
\begin{aligned}
\ln W_{i t}= & \beta_{0}+\sum_{j=1}^{6} \delta_{1 j} f_{a} m_{i t}^{s r}+\sum_{j=1}^{6} \delta_{2 j} f_{a} m_{i t}^{l r}+\eta_{1} \text { unem }_{i t}^{s r} \\
& +\eta_{2} \text { unem }_{i t}^{l r}+\gamma_{1} \text { oth }_{i t}^{s r}+\gamma_{2} \text { oth }_{i t}^{l r}+\beta_{1} X_{i t}+\alpha_{i}+\varepsilon_{i t}
\end{aligned}
$$

\footnotetext{
${ }^{12}$ Composition effects should not occur here, since the number of men and women in the sample is almost equal.
} 
where $W_{i t}$ is the gross hourly wage of individual $i$ at time $t . \delta_{1 j}$ represents the human capital depreciation rate of a career interruption due to family reasons in the short-run (i.e. within the last five years) in each of the $j$ occupational groups, as distinguished in Hypotheses 1 and 2. Thus, the coefficient $\delta_{11}$ for example, is the depreciation rate of an interruption in a high-skilled male occupation. The coefficient $\delta_{2 j}$ represents the depreciation rate of an interruption in the long-run (i.e. the depreciation effect of career interruptions longer than five years ago) in the $j$-th occupational group. ${ }^{13}$ The coefficients $\eta_{1}$ and $\eta_{2}$ measure the human capital depreciation rates of an unemployment spell in the short- or long-run, respectively, and $\gamma_{1}$ and $\gamma_{2}$ measure the short- and long-run depreciation rate of a career interruption due to other reasons, respectively. Note that all coefficients of depreciation rates only measure net depreciation, i.e. it has to be assumed that the interruption periods are not used for further skill-enhancing education.

$X_{i t}$ is a vector of control variables, which includes age, firm size, public or private sector employment, being employed in an occupation with high or low skill requirements, and being employed in a male, female, or integrated occupation. Moreover, we included a dummy for job change. This controls for firm-specific skills obsolescence and occupational mobility. The parameter $\alpha_{i}$ captures individual specific effects, such as ability and motivation.

A common problem of studies employing panel data is that one might face an attrition bias in the analysis. Normal panel attrition can be considered unproblematic as one might assume that the dropping out of the panel occurs randomly. However, another selection problem might be more relevant in our case: we only observe wages of workers who return into employment after a family-related career break, but not the wages of those who do not re-enter the active workforce. Note that we do not control for this selection problem in this paper. Instead, we claim that our estimates of the depreciation rates rather understate the real depreciation rate, because one might assume that in both male and female occupations, particularly workers with the largest wage penalties do not return into wage employment after a career interruption.

\section{Results}

We estimated three versions of the model presented above, with different variables for family-related career interruptions. Model 1 neither distinguishes between male, integrated, and female occupations in estimating the depreciation rates of familyrelated career interruptions, nor between occupations with high or low skill requirements. This specification will help us to show Mincer and Ofek's (1982) restoration effect, and allows comparisons to the coefficients of career interruptions due to unemployment and other reasons. Model 2 does distinguish between

${ }^{13}$ A career interruption only appears in either the short-run or the long-run variable. 
skill levels, but does not distinguish between male, integrated, and female occupations. Finally, model 3 represents the full model of eq. (3). ${ }^{14}$

Table 5 shows our estimation results. Note that we restrict the sample to women only. However, including male workers in the analysis does not alter the results. ${ }^{15}$ The estimation results of model 1 show the overall wage effect of one additional year with a career interruption (column 1). All regression coefficients have the expected signs. Short-run effects of career interruptions are higher than the effect of career interruptions lying longer in the past. This supports Mincer and Ofek's (1982) observation of a restoration phase.

It is also interesting to compare the depreciation rates during family-related career interruptions with the depreciation rates during unemployment and other career interruptions because the motivation for each of these interruption types is entirely different, which might therefore give different signals to the employer and result in different wage penalties (Albrecht et al., 1999). The estimation results show that the short-run depreciation rate after a career break due to family reasons is of similar size as the short-run depreciation rate after career breaks due to unemployment, although the latter is insignificant in the regression. Other interruptions have much greater short-run wage effects than family-related breaks. Moreover, the differences between short- and long-run effects are much more pronounced after career breaks for other reasons.

These results do not confirm the findings by Beblo and Wolf (2002b, 2003) and Kunze (2002) who found that formal parental leave has a stronger wage effect than types of interruptions other than unemployment. ${ }^{16}$ Beblo and Wolf interpret their result as a negative stigma effect attached to parental leave. Other studies have found however, that stigma effects are rather attached to periods of unemployment (cf. Albrecht et al., 1999). Moreover, unemployed workers might indeed be low productivity workers who have been selectively laid off by their former employer (Gibbons and Katz, 1991).

Model 2 enables us to distinguish between depreciation rates for familyrelated career interruptions in occupations with high and low skill requirements (column 2). It is not clear though whether human capital depreciation should

\footnotetext{
${ }^{14}$ Individuals with hourly wage rates higher than $100 €$ are excluded from the regressions. Moreover, those who reported a family-related career interruption but have never worked before are also excluded from the regressions.

${ }^{15}$ The number of male workers with family related career breaks is too small to allow robust inference of its wage effects for male workers.

${ }^{16}$ An explanation for this difference could lie in the different datasets used. Beblo and Wolf and Kunze use the IAB employment panel, which includes only full-time employees in the private sector, while our GSOEP data includes also part-time employees and public sector employees. When there are lower wage penalties in the public sector, this might partly explain our lower depreciation rates. Moreover, Beblo and Wolf do not distinguish between high- and low-skilled occupations, and Kunze only includes lowskilled workers.
} 
Table 5 Estimation results of fixed effects regressions on log gross hourly wages of female workers

(1)

\begin{tabular}{|c|c|c|}
\hline $0.023(0.014)^{\star}$ & $-0.001(0.018)$ & $-0.010(0.019)$ \\
\hline $0.002(0.019)$ & $0.005(0.019)$ & $0.033(0.023)$ \\
\hline$-0.003(0.015)$ & $-0.001(0.015)$ & $0.029(0.020)$ \\
\hline $0.011(0.018)$ & $0.012(0.018)$ & $0.013(0.018)$ \\
\hline $0.284(0.031)^{* * *}$ & $0.287(0.031)^{\star * *}$ & $0.288(0.031)^{* * *}$ \\
\hline$-0.006(0.001)^{* * *}$ & $-0.006(0.001)^{* * *}$ & $-0.006(0.001)^{* * *}$ \\
\hline $4.7 \mathrm{E}-5(6.9 \mathrm{E}-6)^{\star * *}$ & $4.7 \mathrm{E}-5(6.9 \mathrm{E}-6)^{* * *}$ & $4.7 \mathrm{E}-5(6.9 \mathrm{E}-6)^{* * *}$ \\
\hline $0.017(0.020)$ & $0.017(0.020)$ & $0.017(0.020)$ \\
\hline $0.031(0.018)^{*}$ & $0.031(0.018)^{*}$ & $0.031(0.019)^{*}$ \\
\hline $0.061(0.021)^{* * *}$ & $0.060(0.021)^{\star * *}$ & $0.060(0.021)^{* * *}$ \\
\hline $0.073(0.021)^{\star * *}$ & $0.073(0.021)^{\star * *}$ & $0.072(0.021)^{\star * *}$ \\
\hline $0.005(0.014)$ & $0.006(0.014)$ & $0.007(0.014)$ \\
\hline$-0.015(0.012)$ & $-0.015(0.012)$ & $-0.014(0.012)$ \\
\hline$-0.002(0.014)$ & $-0.002(0.014)$ & $-0.003(0.014)$ \\
\hline$-0.053(0.021)^{\star \star}$ & $-0.052(0.021)^{\star \star}$ & $-0.052(0.021)^{\star *}$ \\
\hline$-0.013(0.011)$ & $-0.012(0.011)$ & $-0.013(0.011)$ \\
\hline$-0.019(0.005)^{* * *}$ & & \\
\hline$-0.007(0.004)^{\star \star}$ & & \\
\hline
\end{tabular}

Family-related interruption in occupation

High-skilled (short-run)

Low-skilled (short-run)

High-skilled (long-run)

Low-skilled (long-run)

High-skilled male

(short-run)

High-skilled integrated (short-run)

High-skilled female (short-run)

Low-skilled male (short-run)

Low-skilled integrated

(short-run)

Low-skilled female

(short-run)

High-skilled male (long-run)

High-skilled integrated (long-run)

High-skilled female (long-run)

Low-skilled male (long-run)

Low-skilled integrated (long-run)

Low-skilled female (long-run)

Constant

Observations

Number of persons

$R$-squared
(2)

(3)

$$
\begin{aligned}
& -0.023(0.011)^{\star *} \\
& -0.021(0.008)^{\star *} \\
& -0.001(0.007) \\
& -0.034(0.009)^{\star * *} \\
& -0.022(0.008)^{\star * \star} \\
& -0.023(0.006)^{\star * *} \\
& -0.005(0.007) \\
& -0.009(0.004)^{\star *} \\
& -0.006(0.004) \\
& -0.010(0.005)^{\star *} \\
& -0.012(0.004)^{\star * *} \\
& -0.007(0.004)^{\star} \\
& -1.993(0.387)^{\star * *} \\
& 13536 \\
& 2095 \\
& 0.083
\end{aligned}
$$$$
\begin{array}{cc}
-1.951(0.387)^{\star * *} & -1.979(0.387)^{\star * *} \\
13536 & 13536 \\
2095 & 2095 \\
0.080 & 0.081
\end{array}
$$ 
Table 6 Results of the Wald test for equality of coefficients $\left(\delta_{\text {male }}=\delta_{\text {female }}\right)$

\begin{tabular}{lllll}
\hline & & Test statistic & & Hypothesis \\
\hline \multirow{2}{*}{ Short-run } & High-skilled & F-statistic & 3.36 & $\# 1$ \\
& & p-value & 0.067 & \\
& Low-skilled & F-statistic & 1.09 & $\# 2$ \\
& & p-value & 0.2972 & \\
Long-run & High-skilled & F-statistic & 0.03 & $\# 1$ \\
& & p-value & 0.855 & \\
& Low-skilled & F-statistic & 0.46 & $\# 2$ \\
& & p-value & 0.499 & \\
\hline
\end{tabular}

be higher in high-skilled or in low-skilled occupations. ${ }^{17}$ The estimation results show that the short-run depreciation rate in low-skilled occupations exceeds the short-run depreciation rate in the high-skilled occupations. However, the long-run depreciation rates for low-skilled and high-skilled occupations are similar.

Model 3 finally enables us to test Hypotheses 1 and 2. Looking at short-run depreciation rates during family-related career interruptions, we find a significantly higher depreciation rate in high-skilled male occupations than in female occupations. Depreciation rates are more than two percentage points higher in male occupations. The Wald test of equal coefficients allows rejection of the Null hypothesis of equal coefficients at a 5\% level (using robust standard errors; see Table 6). For the low-skilled occupations, the difference between the depreciation rates for male and female occupations is approximately one percentage point. However, according to the Wald test this difference is not significant.

The estimation results for long-run depreciation rates show a significant negative wage effects for all low-skilled occupations as well as for high-skilled integrated occupations. Estimates range around $1 \%$ in all these cases, which indicates the expected restoration effects. However, the Wald tests do not show significant differences between the long-run depreciation rates in male and female occupations.

To sum up, we find support for Hypothesis 1 in the short run. These results support Polachek's (1981) hypothesis of occupational self-selection into male and female occupations due to differences in human capital depreciation rates for workers with family-related career breaks. While the similar long-run wage effects of family-related career interruptions across all occupations suggest that the longrun effects are not important for occupational choice, the short-run effects will

\footnotetext{
${ }^{17}$ On the one hand, depreciation in occupations with high skill requirements could be higher, because high-skilled workers might be more strongly exposed to technological change (Neuman and Weiss, 1995). On the other hand, depreciation in occupations with low skill requirements could be higher because the skills required in those jobs are often very specific to the occupation, and may therefore be more vulnerable to depreciation during career interruptions than the general skills of workers in highskilled occupations.
} 
probably still be taken into account when workers make their choice in order to maximize life-time earnings.

However, we do not find any evidence for differences in human capital depreciation rates for workers with family-related career breaks in low-skilled occupations (Hypothesis 2). Occupational sex segregation in low-skilled occupations is likely to be the result of other factors, for example traditional gender roles, differences in working conditions (Reed and Dahlquist, 1994), or different opportunities for job flexibility (cf. Bender et al., 2005).

\section{Conclusion and discussion}

In this paper, we estimated human capital depreciation rates during career interruptions due to family reasons on the West German labour market. The rationale for our focus on family-related career interruptions is that they are the only type of career interruptions, which can be taken into account when women choose their occupation. Other types of interruptions, such as unemployment, happen largely unplanned. Moreover, our study differs from most other studies by estimating both short- and long-run human capital depreciation rates.

We estimated a fixed effects model using the German Socio-economic Panel (GSOEP), and determined depreciation rates for six occupational groups (male, integrated, and female occupations with high and low skill requirements, respectively). Our results for short run depreciation in high-skilled occupations are supportive to our hypothesis that human capital depreciation rates during family-related career interruptions are lower in female occupations than in male occupations. This does not hold for low-skilled occupations, however. Long-run depreciation rates are found to be lower than short-run rates, which is in accordance with our expectation of a restoration phase.

Our findings show that different human capital depreciation rates in male and female high-skilled occupations support the theory of occupational self-selection as a determinant of occupational sex segregation in the upper part of the labour market in Germany. This theory argues that women who anticipate career interruptions for family reasons take account of the wage penalties related to such a break when they choose their occupational field, i.e. women select occupations where human capital deprecation during a career interruption is the lowest.

Our estimation results have important implications for public policies which attempt to encourage the interest of female students in technical studies and occupations. Obviously, the higher human-capital depreciation rates for workers with family-related career breaks in these male occupations can be a serious threshold for women to choose these occupations (cf. De Grip and Willems, 2003).

To some extent, our estimation results contradict the findings by England (1982) and Kunze (2002). Both authors find that depreciation rates are higher in female occupations. England's results may be different because she included all types of career interruptions, whereas we focus on interruptions due to family reasons. Moreover, her analysis referred the US where the institutional setting and tradition 
for family leave is different to Germany's. This does not hold for Kunze who also analysed family-related career interruptions on the German labour market. However, as mentioned, Kunze focused solely on young full-time workers who participated in apprenticeship training in the private sector, and did not include high-skilled workers-for which we find the significantly different depreciation rates in male and female occupations-in her analysis. Moreover, Kunze only took account of registered maternity and parental leave, including long-term sick leave, whereas we used a broader definition of family-related career interruptions.

It should be noted that our analysis did not address the question of causality between differences in human capital depreciation rates and occupational selfselection, i.e. our results only support the occupational self-selection theory when women who expect career interruptions due to family reasons take depreciation rates into account ex ante, i.e. before they choose an occupation. Yet, it might also be possible that women only 'discover' ex post-i.e. after having made the choice- that depreciation rates in their occupation are low, and for that reason more easily decide to go on family leave. Furthermore, it could be that depreciation rates in female occupations are lower precisely because so many workers in these jobs have family-related career breaks and employers were able to economize on dealing with this event. Note that such an interpretation would imply that we do not observe true skills obsolescence, but that the observed wage effects are rather mirroring the adjustment costs to the employers (cf. Ondrich et al., 2002). However, when that is the case, the lower depreciation rates in high-skilled female occupations can still reinforce gender segregation, because of the prevailing lower depreciation rates in these occupations.

For future research, we think it would be interesting to estimate depreciation rates, which are truly occupation-specific, i.e. estimating separate depreciation rates for teachers, secretaries, physicians, etc. With those results, one could make even stronger conclusions about the connection between depreciation rates and occupational sex segregation.

\section{Acknowledgement}

The authors thank Ben Kriechel, Anna Matysiak, Jasper van Loo, two anonymous referees, and the guest editors of this special issue for their comments on earlier versions of this paper.

\section{Funding}

European Commission Sixth Framework Programme (029093) to D.G.

\section{References}

Albrecht, J.W., Edin, P.-A., Sundström, M., and Vroman, S.B. (1999) Career interruptions and subsequent earnings: a reexamination using Swedish data, Journal of Human Resources, 34, 294-311. 
Beblo, M. and Wolf, E. (2002a) How much does a year off cost? Estimating the wage effects of employment breaks and part-time periods, Brussels Economic Review/Cahiers Economiques de Bruxelles, 45, 191-217.

Beblo, M. and Wolf, E. (2002b) Wage penalties for career interruptions: an empirical analysis for West Germany, Discussion Paper No. 02-45, ZEW, Mannheim.

Beblo, M. and Wolf, E. (2003) Sind es die Erwerbsunterbrechungen? Ein Erklärungsbeitrag zum Lohnunterschied zwischen Frauen und Männern in Deutschland. (Is it the employment interruptions? A contribution to explaining the wage differentials between men and women in Germany. With English summary), Mitteilungen aus Berufs- und Arbeitsmarktforschung, 36, 560-72.

Beller, A.H. (1982) Occupational segregation by sex: determinants and changes, Journal of Human Resources, 17, 371-92.

Bender, K.A., Donohue, S.M., and Heywood, J.S. (2005) Job satisfaction and gender segregation, Oxford Economic Papers, 57, 479-96.

Boisso, D. (1994) Occupational segregation in the multidimensional case: decomposition and tests of significance, Journal of Econometrics, 61, 161-71.

Borghans, L. and Groot, L. (1999) Educational presorting and occupational segregation, Labour Economics, 6, 375-95.

Datta Gupta, N. and Smith, N. (2000) Children and career interruptions: the family gap in Denmark, CLS Working Papers 00-3, Aarhus School of Business, Centre for Labour Market and Social Research, Aarhus.

Datta Gupta, N. and Smith, N. (2002) Children and career interruptions: the family gap in Denmark, Economica, 69, 609-29.

De Grip, A. and Van Loo, J. (2002) The economics of skills obsolescence: a review, The Economics of Skills Obsolescence, 21, 1-26.

De Grip, A. and Willems, E. (2003) Youngsters and technology, Research Policy, 32, 1771-81.

Edin, P.-A. and Gustavsson, M. (2008) Time out of work and skill depreciation, Industrial and Labor Relations Review, 61, 163-80.

England, P. (1982) The failure of human capital theory to explain occupational sex segregation, Journal of Human Resources, 17, 358-70.

Fain, J.R. (1998) The causes and consequences of occupational segregation: a simultaneous equations approach, Applied Economics, 30, 1361-7.

Federal Statistics Office (2007) Statistisches Jahrbuch 2007 [Statistical Yearbook 2007], Statistisches Bundesamt, Wiesbaden.

Filer, R.K. (1985) Male-female wage differences: the importance of compensating differentials, Industrial and Labor Relations Review, 38, 426-37.

Fitzenberger, B., Schnabel, R., and Wunderlich, G. (2004) The gender gap in labor market participation and employment: a cohort analysis for West Germany, Journal of Population Economics, 17, 83-116.

Gibbons, R. and Katz, L.F. (1991) Layoffs and lemons, Journal of Labor Economics, 9, 351-80.

Groot, W. and Maassen van den Brink, H. (2000) Overeducation in the labor market: a meta-analysis, Economics of Education Review, 19, 149-58. 
Hansen, J. and Wahlberg, R. (2000) Occupational gender composition and wages in Sweden, Discussion Paper No. 217, IZA, Bonn.

Hashimoto, M., Percy, R., Schoellner, T., and Weinberg, B. A. (2004) The long and short of it: maternity leave coverage and women's labor market outcomes, Working Paper, The Ohio State University, Columbus, $\mathrm{OH}$.

International Labour Organization (2004) ISCO_Conceptual Framework, available at http://www.ilo.org/public/english/bureau/stat/isco/isco88/index1.htm.

Jacobsen, J.P. (1998) The Economics of Gender (2nd ed.), Blackwell, Malden, MA.

Jurajda, S. and Harmgart, H. (2003) When are 'female' occupations paying more? Working Paper 202, CERGE-EI, Prague.

Karmel, T. and Maclachlan, M. (1988) Occupational sex segregation. Increasing or decreasing? Economic Record, 64, 187-95.

Kunze, A. (2002) The timing of careers and human capital depreciation, Discussion Paper No. 509, IZA, Bonn.

Lewis, D.E. and Shorten, B. (1991) Occupational Segregation, labour force participation and the relative earnings of men and women, Applied Economics, 23, 167-77.

Light, A. and Ureta, M. (1995) Early-career work experience and gender wage differentials, Journal of Labor Economics, 13, 121-54.

McDowell, J.M. (1982) Obsolescence of knowledge and career publication profiles: some evidence of differences among fields in costs of interrupted careers, The American Economic Review, 72, 752-68.

Merz, M. (2004) Women's hours of market work in Germany: the role of parental leave, Discussion Paper No. 1288, IZA, Bonn.

Mincer, J. (1974) Schooling, Experience and Earnings, Columbia University Press, New York.

Mincer, J. and Ofek, H. (1982) Interrupted work careers: depreciation and restoration of human capital, The Journal of Human Resources, 17, 3-24.

Mincer, J. and Polachek, S. (1974) Family investments in human capital: earnings of women, The Journal of Political Economy, 82, (Part 2: Marriage, Family Human Capital, and Fertility), S76-108.

Mincer, J. and Polachek, S. (1978) An exchange: the theory of human capital and the earnings of women: women's earnings reexamined, Journal of Human Resources, 13, $118-34$.

Neuman, S. and Weiss, A. (1995) On the effects of schooling vintage on experience-earnings profiles: theory and evidence, European Economic Review, 39, 943-55.

Nielsen, H.S., Simonsen, M., and Verner, M. (2004) Does the gap in family-friendly policies drive the family gap? Scandinavian Journal of Economics, 106, 721-44.

Ondrich, J., Spiess, C.K., and Yang, Q. (2002) The effects of maternity leave on women's pay in Germany 1984-1994, Discussion Paper 289, DIW, Berlin.

Polachek, S.W. (1981) Occupational self-selection: a human capital approach to sex differences in occupational structure, The Review of Economics and Statistics, 63, 60-9.

Ramirez, J.V. (2002) Age and schooling vintage effects on earnings profiles in Switzerland, in A. De Grip and J. Van Loo (eds) The Economics of Skills Obsolescence (Vol. 21, Research in Labor Economics), JAI Press, Amsterdam and Boston. 
Reed, W.R. and Dahlquist, J. (1994) Do women prefer women's work? Applied Economics, 26, 1133-44.

Rosenfeld, R.A., Trappe, H., and Gornick, J.C. (2004) Gender and work in Germany: before and after the reunification, Annual Review of Sociology, 30, 103-24.

Ruhm, C.J. (1998) The economic consequences of parental leave mandates: lessons from Europe, The Quarterly Journal of Economics, 113, 285-317.

Trappe, H. and Rosenfeld, R.A. (2004) Occupational sex segregation and family formation in the former East and West Germany, Work and Occupations, 31, 155-92.

\section{Appendix}

Table A1 Frequency of occurrence and classification of ISCO codes

\begin{tabular}{|c|c|c|c|c|c|}
\hline Isco & Occupations & Female no. & Male no. & $\%$ male & Classification \\
\hline 11 & Armed forces & & 109233 & 100 & male \\
\hline 111 & $\begin{array}{l}\text { Legislators and senior government } \\
\text { officials }\end{array}$ & & 3371 & 100 & male \\
\hline 114 & $\begin{array}{l}\text { Senior officials of special-interest } \\
\text { organizations }\end{array}$ & 4043 & 12796 & 75.99 & male \\
\hline 120 & Corporate managers & & 44704 & 100 & male \\
\hline 121 & Directors and chief executives & 26778 & 197823 & 88.08 & male \\
\hline 122 & $\begin{array}{l}\text { Production and operations } \\
\text { managers }\end{array}$ & 10197 & 244056 & 95.99 & male \\
\hline 123 & Other specialist managers & 81050 & 258413 & 76.12 & male \\
\hline 130 & General managers & 18239 & 60708 & 76.9 & male \\
\hline 131 & Managers of small enterprises & 81791 & 236537 & 74.31 & male \\
\hline 211 & $\begin{array}{l}\text { Physicists, chemists, and related } \\
\text { professionals }\end{array}$ & 13974 & 20880 & 59.91 & integrated \\
\hline 213 & Computing professionals & 14297 & 244879 & 94.48 & male \\
\hline 214 & $\begin{array}{l}\text { Architects, engineers, and related } \\
\text { professionals }\end{array}$ & 45791 & 607066 & 92.99 & male \\
\hline 221 & Life science professionals & & 7450 & 100 & male \\
\hline 222 & $\begin{array}{l}\text { Health professionals (except } \\
\text { nursing) }\end{array}$ & 141107 & 169490 & 54.57 & integrated \\
\hline 231 & $\begin{array}{l}\text { College, university, and higher } \\
\text { education teaching professionals }\end{array}$ & 5281 & 99925 & 94.98 & male \\
\hline 232 & $\begin{array}{l}\text { Secondary education teaching } \\
\text { professionals }\end{array}$ & 280557 & 220565 & 44.01 & integrated \\
\hline 233 & $\begin{array}{l}\text { Primary and pre-primary educa- } \\
\text { tion teaching professionals }\end{array}$ & 100555 & 15902 & 13.65 & female \\
\hline 234 & $\begin{array}{l}\text { Special education teaching } \\
\text { professionals }\end{array}$ & 15394 & 41114 & 72.76 & male \\
\hline 235 & Other teaching professionals & 66081 & 38584 & 36.86 & integrated \\
\hline 240 & Other professionals & & 9782 & 100 & male \\
\hline 241 & Business professionals & 33516 & 213591 & 86.44 & male \\
\hline 242 & Legal professionals & 19698 & 33038 & 62.65 & integrated \\
\hline 243 & $\begin{array}{l}\text { Archivists, librarians, and related } \\
\text { information professionals }\end{array}$ & 52339 & & 0 & female \\
\hline
\end{tabular}


Table A1 Continued

\begin{tabular}{|c|c|c|c|c|c|}
\hline Isco & Occupations & Female no. & Male no. & $\%$ male & Classification \\
\hline 244 & $\begin{array}{l}\text { Social science and related } \\
\text { professionals }\end{array}$ & 165670 & 90249 & 35.26 & integrated \\
\hline 245 & $\begin{array}{l}\text { Writers and creative or performing } \\
\text { artists }\end{array}$ & 126682 & 36354 & 22.3 & female \\
\hline 246 & Religious professionals & & 35268 & 100 & male \\
\hline 247 & $\begin{array}{l}\text { Public service administrative } \\
\text { professionals }\end{array}$ & 189837 & 257991 & 57.61 & integrated \\
\hline 311 & $\begin{array}{l}\text { Physical and engineering science } \\
\text { technicians }\end{array}$ & 132271 & 436710 & 76.75 & male \\
\hline 312 & Computer associate professionals & 40594 & 129685 & 76.16 & male \\
\hline 313 & $\begin{array}{l}\text { Optical and electronic equipment } \\
\text { operators }\end{array}$ & 9548 & 18995 & 66.55 & integrated \\
\hline 314 & $\begin{array}{l}\text { Ship and aircraft controllers and } \\
\text { technicians }\end{array}$ & & 69586 & 100 & male \\
\hline 315 & Safety and quality inspectors & 15386 & 80157 & 83.9 & male \\
\hline 321 & $\begin{array}{l}\text { Life science technicians and related } \\
\text { associate professional }\end{array}$ & 50745 & 1416 & 2.71 & female \\
\hline 322 & $\begin{array}{l}\text { Health associate professionals } \\
\text { (except nursing) }\end{array}$ & 131729 & 62927 & 32.33 & female \\
\hline 323 & $\begin{array}{l}\text { Nursing and midwifery associate } \\
\text { professionals }\end{array}$ & 421277 & 76545 & 15.38 & female \\
\hline 332 & $\begin{array}{l}\text { Pre-primary education teaching } \\
\text { associate professionals }\end{array}$ & 239745 & 22710 & 8.65 & female \\
\hline 333 & $\begin{array}{l}\text { Special education teaching associ- } \\
\text { ate professionals }\end{array}$ & 18385 & & 0 & female \\
\hline 334 & $\begin{array}{l}\text { Other teaching associate } \\
\text { professionals }\end{array}$ & 27261 & 44260 & 61.88 & integrated \\
\hline 341 & $\begin{array}{l}\text { Finance and sales associate } \\
\text { professionals }\end{array}$ & 375234 & 395978 & 51.34 & integrated \\
\hline 342 & $\begin{array}{l}\text { Business services agents and trade } \\
\text { brokers }\end{array}$ & 36429 & 101653 & 73.62 & male \\
\hline 343 & $\begin{array}{l}\text { Administrative associate } \\
\text { professionals }\end{array}$ & 792077 & 232034 & 22.66 & female \\
\hline 344 & $\begin{array}{l}\text { Customs, tax, and related } \\
\text { government } \\
\text { associate professionals }\end{array}$ & 243433 & 130318 & 34.87 & integrated \\
\hline 345 & Police inspectors and detectives & 19241 & 208763 & 91.56 & male \\
\hline 346 & Social work associate professionals & 167020 & 41954 & 20.08 & female \\
\hline 347 & $\begin{array}{l}\text { Artistic, entertainment, and sports } \\
\text { associate professionals }\end{array}$ & 87937 & 12669 & 12.59 & female \\
\hline 348 & Religious associate professionals & 11532 & & 0 & female \\
\hline 411 & $\begin{array}{l}\text { Secretaries and keyboard- } \\
\text { operating clerks }\end{array}$ & 235585 & & 0 & female \\
\hline 412 & Numerical clerks & 325595 & 222720 & 40.62 & integrated \\
\hline 413 & $\begin{array}{l}\text { Material-recording and transport } \\
\text { clerks }\end{array}$ & 214663 & 259502 & 54.73 & integrated \\
\hline 414 & Library, mail, and related clerks & 36409 & 41698 & 53.39 & integrated \\
\hline 419 & Other office clerks & 576070 & 78873 & 12.04 & female \\
\hline 421 & Cashiers, tellers, and related clerks & 163108 & 33150 & 16.89 & female \\
\hline
\end{tabular}


Table A1 Continued

\begin{tabular}{|c|c|c|c|c|c|}
\hline Isco & Occupations & Female no. & Male no. & $\%$ male & Classification \\
\hline 422 & Client information clerks & 161187 & 27446 & 14.55 & female \\
\hline 511 & $\begin{array}{l}\text { Travel attendants and related } \\
\text { workers }\end{array}$ & 13613 & 2506 & 15.55 & female \\
\hline 512 & $\begin{array}{l}\text { Housekeeping and restaurant } \\
\text { services workers }\end{array}$ & 257382 & 169532 & 39.71 & integrated \\
\hline 513 & Personal care and related workers & 589635 & 77003 & 11.55 & female \\
\hline 514 & Other personal services workers & 206283 & 63436 & 23.52 & female \\
\hline 516 & Protective services workers & 88249 & 102978 & 53.85 & integrated \\
\hline 522 & $\begin{array}{l}\text { Shop, stall, and market } \\
\text { salespersons and demonstrators }\end{array}$ & 722171 & 126161 & 14.87 & female \\
\hline 610 & $\begin{array}{l}\text { Market-oriented, skilled } \\
\text { agricultural, and fishery workers }\end{array}$ & 12753 & 65156 & 83.63 & male \\
\hline 611 & $\begin{array}{l}\text { Market gardeners and crop } \\
\text { growers }\end{array}$ & 49091 & 54468 & 52.6 & integrated \\
\hline 612 & $\begin{array}{l}\text { Animal producers and related } \\
\text { workers }\end{array}$ & 43413 & & 0 & female \\
\hline 614 & Forestry and related workers & & 6355 & 100 & male \\
\hline 711 & $\begin{array}{l}\text { Miners, shotfirers, stone cutters, } \\
\text { and carvers }\end{array}$ & & 986 & 100 & male \\
\hline 712 & $\begin{array}{l}\text { Building frame and related trades } \\
\text { workers }\end{array}$ & 10160 & 169156 & 94.33 & male \\
\hline 713 & $\begin{array}{l}\text { Building finishers and related } \\
\text { trades workers }\end{array}$ & 22302 & 394250 & 94.65 & male \\
\hline 714 & $\begin{array}{l}\text { Painters, building structure } \\
\text { cleaners and s } \\
\text { related trades worker }\end{array}$ & 16045 & 205690 & 92.76 & male \\
\hline 721 & $\begin{array}{l}\text { Metal moulders, welders, sheet- } \\
\text { metal workers, structural-metal } \\
\text { preparers, and related trades } \\
\text { workers }\end{array}$ & 6751 & 144761 & 95.54 & male \\
\hline 722 & $\begin{array}{l}\text { Blacksmiths, tool-makers, and } \\
\text { related trades } \\
\text { workers }\end{array}$ & 3695 & 206408 & 98.24 & male \\
\hline 723 & Machinery mechanics and fitters & 38923 & 468117 & 92.32 & male \\
\hline 724 & $\begin{array}{l}\text { Electrical and electronic equip- } \\
\text { ment mechanics and fitters }\end{array}$ & 7527 & 285634 & 97.43 & male \\
\hline 731 & $\begin{array}{l}\text { Precision workers in metal and } \\
\text { related materials }\end{array}$ & 26213 & 98851 & 79.04 & male \\
\hline 732 & $\begin{array}{l}\text { Potters, glass-makers, and related } \\
\text { trades workers }\end{array}$ & 57093 & 967 & 1.67 & female \\
\hline 734 & $\begin{array}{l}\text { Craft printing and related trades } \\
\text { workers }\end{array}$ & 19411 & 62742 & 76.37 & male \\
\hline 741 & $\begin{array}{l}\text { Food processing and related trades } \\
\text { workers }\end{array}$ & 9990 & 131808 & 92.95 & male \\
\hline 742 & $\begin{array}{l}\text { Wood treaters, cabinet-makers, } \\
\text { and related trades workers }\end{array}$ & 703 & 111934 & 99.38 & male \\
\hline 743 & $\begin{array}{l}\text { Textile, garment, and related } \\
\text { trades workers }\end{array}$ & 46745 & 5211 & 10.03 & female \\
\hline 744 & $\begin{array}{l}\text { Pelt, leather, and shoemaking } \\
\text { trades workers }\end{array}$ & 2267 & 10679 & 82.49 & male \\
\hline
\end{tabular}


Table A1 Continued

\begin{tabular}{|c|c|c|c|c|c|}
\hline Isco & Occupations & Female no. & Male no. & $\%$ male & Classification \\
\hline 811 & $\begin{array}{l}\text { Mining and mineral-processing- } \\
\text { plant operators }\end{array}$ & & 3592 & 100 & male \\
\hline 812 & Metal-processing plant operators & 528 & 7928 & 93.75 & male \\
\hline 814 & $\begin{array}{l}\text { Wood-processing- and } \\
\text { papermaking-plant operators }\end{array}$ & 3601 & 29211 & 89.03 & male \\
\hline 815 & $\begin{array}{l}\text { Chemical-processing-plant } \\
\text { operators }\end{array}$ & 16368 & 101209 & 86.08 & male \\
\hline 816 & $\begin{array}{l}\text { Power-production and related } \\
\text { plant operators }\end{array}$ & 7623 & 64827 & 89.48 & male \\
\hline 821 & $\begin{array}{l}\text { Metal- and mineral-products } \\
\text { machine operators }\end{array}$ & 25329 & 184674 & 87.94 & male \\
\hline 822 & $\begin{array}{l}\text { Chemical-products machine } \\
\text { operators }\end{array}$ & 14709 & 4325 & 22.72 & female \\
\hline 823 & $\begin{array}{l}\text { Rubber- and plastic-products } \\
\text { machine operators }\end{array}$ & 23545 & 54068 & 69.66 & male \\
\hline 824 & $\begin{array}{l}\text { Wood-products machine } \\
\text { operators }\end{array}$ & & 7861 & 100 & male \\
\hline 825 & $\begin{array}{l}\text { Printing-, binding-, and paper- } \\
\text { products machine operators }\end{array}$ & 1540 & 42320 & 96.49 & male \\
\hline 826 & $\begin{array}{l}\text { Textile-, fur-, and leather-products } \\
\text { machine operators }\end{array}$ & 37759 & 6686 & 15.04 & female \\
\hline 827 & $\begin{array}{l}\text { Food and related products } \\
\text { machine operators }\end{array}$ & 13513 & 51969 & 79.36 & male \\
\hline 828 & Assemblers & 49516 & 54357 & 52.33 & integrated \\
\hline 829 & $\begin{array}{l}\text { Other machine operators not } \\
\text { elsewhere classified }\end{array}$ & & 51433 & 100 & male \\
\hline 831 & $\begin{array}{l}\text { Locomotive engine drivers and } \\
\text { related workers }\end{array}$ & & 67879 & 100 & male \\
\hline 832 & Motor vehicle drivers & 84095 & 292340 & 77.66 & male \\
\hline 833 & $\begin{array}{l}\text { Agricultural and other mobile } \\
\text { plant operators }\end{array}$ & 23280 & 82281 & 77.95 & male \\
\hline 913 & $\begin{array}{l}\text { Domestic and related helpers, } \\
\text { cleaners, and launderers }\end{array}$ & 534568 & 10308 & 1.89 & female \\
\hline 914 & $\begin{array}{l}\text { Building caretakers, window and } \\
\text { related cleaners }\end{array}$ & 36228 & 124880 & 77.51 & male \\
\hline 915 & $\begin{array}{l}\text { Messengers, porters, doorkeepers, } \\
\text { and related workers }\end{array}$ & 67579 & 32301 & 32.34 & female \\
\hline 916 & $\begin{array}{l}\text { Garbage collectors and related } \\
\text { labourers }\end{array}$ & 3170 & 36412 & 91.99 & male \\
\hline 921 & $\begin{array}{l}\text { Agricultural, fishery, and related } \\
\text { labourers }\end{array}$ & 8189 & 15600 & 65.58 & integrated \\
\hline 931 & Mining and construction labourers & & 44082 & 100 & male \\
\hline 932 & Manufacturing labourers & 152878 & 149015 & 49.36 & integrated \\
\hline 933 & $\begin{array}{l}\text { Transport labourers and freight } \\
\text { handlers }\end{array}$ & 12973 & 145469 & 91.81 & male \\
\hline 993 & GSOEP specific & 3945 & 2805 & 41.56 & integrated \\
\hline 996 & GSOEP specific & 3608 & & 0 & female \\
\hline 997 & GSOEP specific & 633 & 6872 & 91.56 & male \\
\hline 998 & GSOEP specific & 29944 & 12102 & 28.78 & female \\
\hline
\end{tabular}

Source: GSOEP, waves 2004 and 2005; own calculations. Cross-sectional weights as provided by the GSOEP have been used in the calculations. 